International Review of Research in Open and Distributed Learning Volume 19, Number 5

November - 2018

\title{
Characterization of the Reasons Why Brazilian Science Teachers Drop Out of Online Professional Development Courses
}

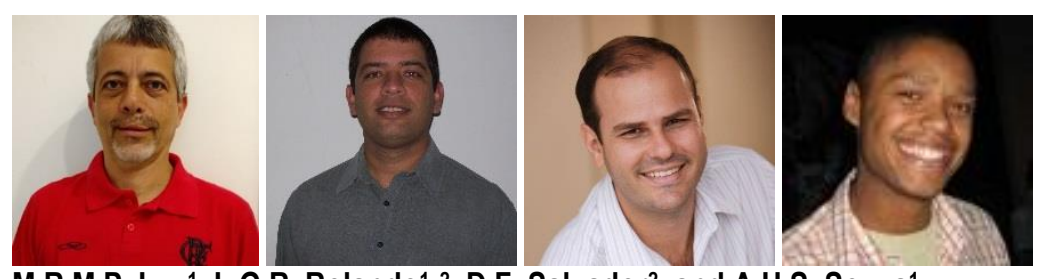

M.R.M.P. Luz', L.G.R. Rolando', 2, D.F. Salvador ${ }^{2}$, and A.H.S. Souza1

${ }^{1}$ Instituto Oswaldo Cruz, Laboratório Avaliação em Ensino e Filosofia das Biociências; ${ }^{2}$ Fundação Centro de Ciências e Educação Superior a Distância

\begin{abstract}
Teachers face different challenges and opportunities through distance education. We used a combination of quantitative and qualitative approaches to investigate the factors leading in-service science teachers to quit online courses. No differences were found between persistent and drop-out teachers based on their sociodemographic data and their technological skills. The dropout rates were unrelated to courses' contents or duration. A follow-up procedure revealed that a heavy workload and technological issues accounted for most of the reasons teachers left courses. We conclude that financial incentives and reduced workload are key factors that could minimize attrition and increase persistence among Brazilian teachers.
\end{abstract}

Keywords: online courses, dropout, teacher education, lifelong learning 


\section{Introduction}

The models used to explain why learners drop out of face-to-face or online courses are constantly changing. New models usually rely on their predecessors to incorporate the features of new educational settings or of different learner profiles. Because dropout rates are influenced by factors related to learner profile (e.g., traditional or non-traditional) and educational settings (e.g., face-to-face or distance education), most models share common characteristics, but also differ on important features.

\section{Dropout Models: From Traditional Students in College to Non-Traditional Learners in Distance Education}

Early frameworks designed to explain dropout processes were developed for traditional learners in traditional settings, that is, for young students attending face-to-face college courses. Among those, Tinto's (1993) model has long been considered the most influential (Bean \& Metzner, 1985; Kember, 1989; Rovai, 2003). The model describes the dropout process as a longitudinal series of interactions between an individual and other students, as well as college faculty and staff (Tinto, 1993). Individual integration into the college community continually modifies, either positively or negatively, the students' intentions and commitments, which in turn influences their decision to leave or to stay at the institution. Tinto's (1993) model predicts that students' involvement with the college community and their positive interactions with their peers and college faculty are key factors behind their decision to remain a student, while the failure to establish such interactions and to fit in their educational environment is likely to increase dropout rates (Rovai, 2003). Tinto's (1993) model was developed for explaining attrition among traditional college students (young resident students) for whom academic and social integration within college or university are very influential. In the last few decades, however, the number of non-traditional learners has grown exponentially (Bean \& Metzner, 1985). Non-traditional learners were initially considered somewhat synonymous with commuting students (Tinto, 1993). Bean and Metzner (1985) admitted that it was difficult to profile such students as they were very heterogeneous in terms of ethnicity, gender, and origin, among several other factors. The authors opted for a definition of non-traditional learners that contrasted some of their key features with those of traditional students; specifically, they categorized students that were mature, had enrolled in part-time courses, usually did not live in a college dorm, commuted to classes, and were more likely to have jobs as the non-traditional students (Bean \& Metzner, 1985). Due to their maturity and less frequent interactions with the other members of the college community, non-traditional learners were considered unlikely to be as susceptible to the socialization and integration issues that more traditional learners face (Bean \& Metzner, 1985). Although Tinto's (1993) model was recognized as a powerful tool, it has been suggested that it has several limitations when it comes to explaining non-traditional student dropout processes (Bean \& Metzner, 1985; Kember, 1989; Rovai, 2003). Because prior models to explain dropout relied heavily on social processes to explain attrition, Bean and Metzner (1985) suggested another model to explain non-traditional learners' reasons to drop out. In general terms, Bean and Metzner's (1985) model comprises academic, background, and environmental variables, as well as student academic and psychological outcomes. Environmental variables are thought to have more impact on dropout rates for non-traditional students than academic variables, primarily due to the fact that supportive environments (e.g., healthy finances or good child care management) might help non-traditional students to continue their education even when academic performance or support is weak (Bean \& Metzner, 1985). As such, the 
rise of distance education has posed new challenges to the study of student attrition. Distance education courses are increasingly common for both traditional and non-traditional learners. Those courses are typically non-traditional processes of education in the sense that they seldom involve face-to-face interactions or the presence of learning groups (Kember, 1989). Models used to explain dropout processes that proved applicable to either type of students in face-to-face settings needed to be reformulated in order to address issues related to the new educational environments.

Non-traditional learners face different challenges and opportunities through distance education, such as an asynchronous learning environment and adaptive study schedules. An early study suggested that factors influencing dropout rates could be generally recognized as what the author called "characteristics" or "circumstances" (Kennedy \& Powell, 1976). The former were hard or slow to change, as they had an intrinsic value (e.g., educational background), while the latter could change more readily because they comprised items such as the learner's finances and family relationships. More recently, new frameworks were suggested for dealing with the dropout process from online courses. Rovai's (2003) composite persistence model aimed to explain the factors that affect a learners' decision to drop out from online courses and included two prior-to-admission variables, namely students' skills (e.g., computer literacy and information literacy) and students' characteristics (e.g., age, ethnicity, and gender). The framework also included two after-admission variables, the so-called external factors (e.g., finances, hours of employment) and internal factors (e.g., social integration, goal commitment, and course utility).

Based on Rovai's (2003) earlier work, Park (2007) suggested a new revised framework for understanding the factors affecting non-traditional and non-degree online program learners' decision to drop out. In this new theoretical framework, some variables were relocated while new relations between variables were proposed. For instance, learner skills were set apart on the basis of the lack of sufficient empirical studies to support their relevance (Park, 2007). Moreover, the author suggested that external factors affect learners' decisions not only during, but also before, the courses, and thus could influence learners' decision to drop out at the two stages.

\section{Online Professional Development Programs for Teachers}

In the last decade, the number of opportunities for adult learners has increased at both graduate and undergraduate levels, as well as in professional development courses (Allen \& Seaman, 2016; Bersin, 2005; Ministério da Educação, 2010). Almost three million students (roughly 14\% of all higher education students) were attending higher education online courses in 2014 in the U.S.A. (Allen \& Seaman, 2016). In this context, several authors have suggested the urgency of developing online development programs specifically aimed at teachers in order to enable them to use information and communications technology (ICT) effectively and to improve the quality of their teaching (Kenski, 2009; National Research Council, 2007; UNESCO, 2008; Villani, Almeida-Pacca, \& Freitas, 2009). More often than not, however, online courses have suffered with high levels of attrition (Favero \& Franco, 2006; Frydenberg, 2007; Hart, 2012; Levy, 2007; Lykourentzou, Giannoukos, Nikolopoulos, Mpardis, \& Loumos, 2009; Meister, 2002; Park \& Choi, 2009; Yukselturk, 2010). Even if distance education is commonly accompanied by attrition and high dropout rates, the use of online courses may still be a useful alternative to face-to-face courses for teachers' ongoing education, specifically in countries with near-continental dimensions yet with limited resources to 
invest in ongoing teacher development. Indeed, a recent study showed indistinguishable outcomes between face-to-face and online professional development courses for teachers (Fishman et al., 2016).

Teachers fit the definition of non-traditional adult learners but their profession is known to be characterized by high levels of attrition and dropout rates due to many factors, such as financial and geographical issues (Borman \& Dowling, 2008; Ingersoll \& Perda, 2009; Karsenti \& Collin, 2013; Macdonald, 1999). Those are also major issues in Brazil, where an early report suggested that the number of teachers quitting their jobs in the past decade had increased up to 300\% (Lapo \& Bueno, 2003). That massive increase in resignation was caused mainly by low wages, poor working conditions, and lack of professional perspectives (Lapo \& Bueno, 2003). Official Brazilian documents have also emphasized the need for a consistent teacher training policy (Conferência Nacional de Educação, 2010).

There are quite few studies on Online Professional Development Programs (OPDP) dropout rates among teachers. Most of those studies report dropout rates ranging from 30\% to 40\% (Russell, Carey, Kleiman, \& Venable, 2009; Kubitskey et al., 2012, Stiller \& Bachmayer, 2017). There is no consensus in the literature regarding a definition of a dropout. The fact that these studies deal with different educational settings adds to the difficulty of making generalizations. Little is known about the specific patterns of dropout or about the reasons why teachers decide to drop out of online courses. High dropout rates impose losses to educational systems in countries where resources are already scarce. The present study took advantage of an existing online development program aimed at science teachers being developed in Brazil to characterize the reasons for dropping out within a broad sample of teachers. We have used a combination of quantitative and qualitative data to address the main research question: What factors influence the dropout rates among Brazilian teachers enrolled in online professional development programs?"

\section{Methods}

\section{The Online Courses}

An online professional development program for science teachers comprising seven different non-degree courses was offered by CECIERJ throughout the three years of the present study (from 2010 to 2012). Courses are made available on Moodle free of charge and provided 30 hours of core work each. The courses were: Introductory Microbiology (MIC), Integrated Human Health (HHE), Introductory Botany (IBO), Understanding the Environment (ENV), Biodiversity (DIV), Sexuality and Education (SED), and Collaborative Technologies and Biology Education (TBE). Each pedagogical unit (course module) had the following components: lesson plans, main texts, additional texts, multimedia resources (animations, videos, simulators), and the distance activities (DAs). All courses comprised of: (i) discussion forums where members could take part in discussions about pedagogical issues and course contents, and supervised by tutors; and (ii) assignments (all teachers received formative feedback from tutors). Each course comprised six DAs to be handed in according to a previously agreed schedule and a final paper to be submitted after the completion of the DAs. Courses were offered in both 12 and 16-week terms, with the final paper submition as a mandatory requirement to receive a certification of completion. The certification has no 
impact on the teachers' income or career development. All courses were coordinated by online tutors who were responsible for supporting learners in their assigned tasks and for motivating them to pursue their goals and complete their courses. The tutors were supervised by at least one faculty member with prior experience in teaching and research on the specific course subject.

\section{Sample}

The online courses were offered by the state government and were aimed preferentially at teachers from public schools (Salvador, Crapez, Rolando, Rolando, \& Magarão, 2010). The original sample to be analyzed in the present study comprised the 3,026 teachers who enrolled in at least one course during three consecutive years.

Candidates filled online applications in which they should inform their educational background, teaching subjects, and professional affiliation. The applications always exceeded the number of spaces available. Criteria for admission were used and preference was given to qualified biology and science teachers working at public schools. All the applicants that fulfilled those two criteria were admitted.

Demographic information, as well as data on teachers' use of internet tools, were obtained by means of an online questionnaire (Rolando, Salvador, \& Luz, 2013). Briefly, the questionnaire consisted of closed-ended questions on whether or not each tool from a set of 13 different internet tools was used by each respondent. This analysis was based on a sample of 2,491 teachers ( $82 \%$ of the original sample) that provided demographic data and filled the questionnaires.

\section{Characterization of Dropout Patterns and Rates}

The learning management system (LMS) Moodle available allowed for the identification of teachers that delivered each of the DAs within their respective deadline. Although it was not unusual for teachers to miss one or a couple DAs throughout the courses; however, those who missed two consecutive DAs did not continue doing the course (see below).

In the present study we were interested in characterizing the factors that determine dropout rates and patterns rather than in the effectiveness of the courses. What it means to be a dropout in an online course vary in the literature (Grau-Valldosera \& Minguillón, 2014; Levy, 2007; Lee \& Choi, 2011). Although a general definition would be desirable, we believe that it is unattainable due to the inevitable differences in the educational settings of each study. Nevertheless, a clear definition must be presented in each study to make the necessary comparisons feasible. In the present study, a dropout teacher was defined as one that did not submit their final paper; the final paper was the only mandatory activity of the courses analyzed. Failing to hand the final paper in was defined as equivalent to failing the course; therefore, a teacher was considered as a dropout if he/she failed to submit their final paper regardless of the number of DAs handed in during the course. On the other hand, a teacher was considered persistent if he/she handed in the final paper, regardless of passing or failing the course. It is noteworthy that all teachers who failed to submit their final paper had also failed to hand in one or more DAs prior to the final paper and did not return to the virtual classrooms after prolonged absences. Those findings support the assumption that they had effectively left the course prior to its closure and that the definition of dropout adopted in the present study was adequate. 


\section{Understanding the Reasons for Dropping Out}

A follow-up procedure adapted Nistor and Neubauer (2010) was implemented and helped to promptly identify and contact dropouts. This procedure was adopted during two 16-week courses. The procedure was based on emails sent after an absence of seven consecutive days from the virtual classroom. The message included an invitation to rejoin the course as well as questions about the teachers' intention to return or not to the courses (Appendix A). All teachers that replied to the emails presented explanations for abandoning the courses and none of them returned to the virtual classroom or rejoined the course afterwards. Their replies were therefore included in the data sample used in the characterization of the reasons for dropping out. Teachers that did not reply to the email and missed two DAs after the email was sent were contacted by telephone for a short interview. The interview focused on the reasons for abandoning the course (Appendix B). This procedure was slightly adapted for the sixth DA (DA6) because the time interval between the deadline for handing in the DA6 and the deadline for submitting the mandatory final paper was shorter. The 21 teachers who failed the DA6 but submitted the final paper were not contacted by email or telephone, as they were not considered dropouts from the course. None of the teachers contacted by email or interviewed by phone throughout the whole process submitted the mandatory final paper. Those additional findings corroborate the previous assumption that they all had indeed opted to drop out from the courses. Replies to emails ( $n=45)$ and transcriptions of phone interviews $(n=104)$ were pooled and used for further analysis. The categorization of replies to email messages and transcriptions of phone interviews followed a content analysis procedure (Fraenkel \& Wallen, 2003). The categories (Table 1) were based on Rovai's (2003) and Park's (2007) theoretical frameworks. Teachers' answers were independently categorized by two coders with an agreement of $97 \%$ between them (disagreements were coded by consensus).

Table 1

Categories of Teachers'Answers to E-mail Messages or Phone Calls

\begin{tabular}{|c|c|c|c|}
\hline Type & Category & Definition & Examples \\
\hline \multirow{2}{*}{ Internal } & \multirow{2}{*}{ Technology issues } & \multirow{2}{*}{$\begin{array}{l}\text { Technical difficulties in using } \\
\text { computers, accessing the internet, or } \\
\text { using the course's platform. }\end{array}$} & $\begin{array}{l}\text { "My home computer broke and I do not } \\
\text { have access to the internet anywhere } \\
\text { else." }\end{array}$ \\
\hline & & & $\begin{array}{l}\text { "My internet connection was too slow } \\
\text { and I couldn't follow the courses } \\
\text { effectively." }\end{array}$ \\
\hline \multirow{3}{*}{ External } & Schedule conflicts & $\begin{array}{l}\text { Failing to cope with the course's } \\
\text { activities due to lack of time and/or } \\
\text { excessive workload. }\end{array}$ & $\begin{array}{l}\text { "I am currently working in two different } \\
\text { schools so I do not have time to follow } \\
\text { the course." }\end{array}$ \\
\hline & Family issues & Need to deal with family obligations. & $\begin{array}{l}\text { "My daughter is going through a } \\
\text { difficult pregnancy and needs my } \\
\text { support." }\end{array}$ \\
\hline & Personal issues & $\begin{array}{l}\text { Reasons that do not fit any of the } \\
\text { other categories. }\end{array}$ & $\begin{array}{l}\text { "I am going to undergo a surgery and } \\
\text { can no longer follow the course." }\end{array}$ \\
\hline
\end{tabular}




\section{Results}

\section{Dropout Patterns and Rates}

A total of 3,026 teachers joined at least one of the 19 groups attending the seven different courses available during the present study (Table 2). Only $17.7 \%$ of the teachers did not join their courses at any time while the remaining $82.3 \%$ handed in at least the first DA. A total of 1,543 teachers (46.9\%) completed their courses by submitting the final paper resulting in a global dropout rate of $53.1 \%$ (Table 2). Dropout rates ranged from $45 \%$ to $56 \%$ depending on the course. Statistical analysis weren't carried out to compare dropout rates in different courses because many of them were offered only once or twice. Differences of about $10 \%$ in dropout rates could be found between courses on different subjects as well as between a course that was offered twice (not shown). The heterogeneity in dropout rates seems thus unlikely to be related to course subjects. The percentage of teachers that remained in the courses by handing in the DAs according to the schedule, fell gradually and similarly along both the 12 and 16-week courses (Figure 1). A total of 182 teachers failed to hand in DA6 but submitted the final paper, perhaps because only the latter was mandatory. That explains the slight inflexion in the persistency curve after DA6 (Figure 1).The percentage of persistent teachers was significantly greater in 16-week courses considering the deadlines for DA2 and DA3 but no significant differences in persistence could be found after that (Figure 1). The total percentages of persistent teachers in 12 and 16-week courses were similar (46.5\% and 47.3\%, respectively) and no significant differences were found between the total dropout rates in the two contexts ( $\mathrm{p}=1.0$, MannWhitney test). The total percentage of persistent teachers was also very similar when the only two courses offered in both 14 and 16 -week terms were considered (55.3\% and 53.8\%, respectively). The similarity in the dropout rates in courses on different subjects, as well as the similar final dropout rates regardless of course duration, suggested that the teachers' decision to dropout was unrelated to a courses' content or duration.

Table 2

Sample Composition and Dropout Rates in 12 and 16 Weeks' Courses

\begin{tabular}{ccccc}
\hline $\begin{array}{c}\text { Term } \\
\text { duration }\end{array}$ & Courses & Groups & Teachers (n) & Final dropout \\
\hline 12 weeks & 4 & 9 & 1622 & $53.5 \%$ \\
16 weeks & 5 & 10 & 1404 & $52,7 \%$ \\
Total & 9 & 19 & 3026 & $53.1 \%$ \\
\hline
\end{tabular}




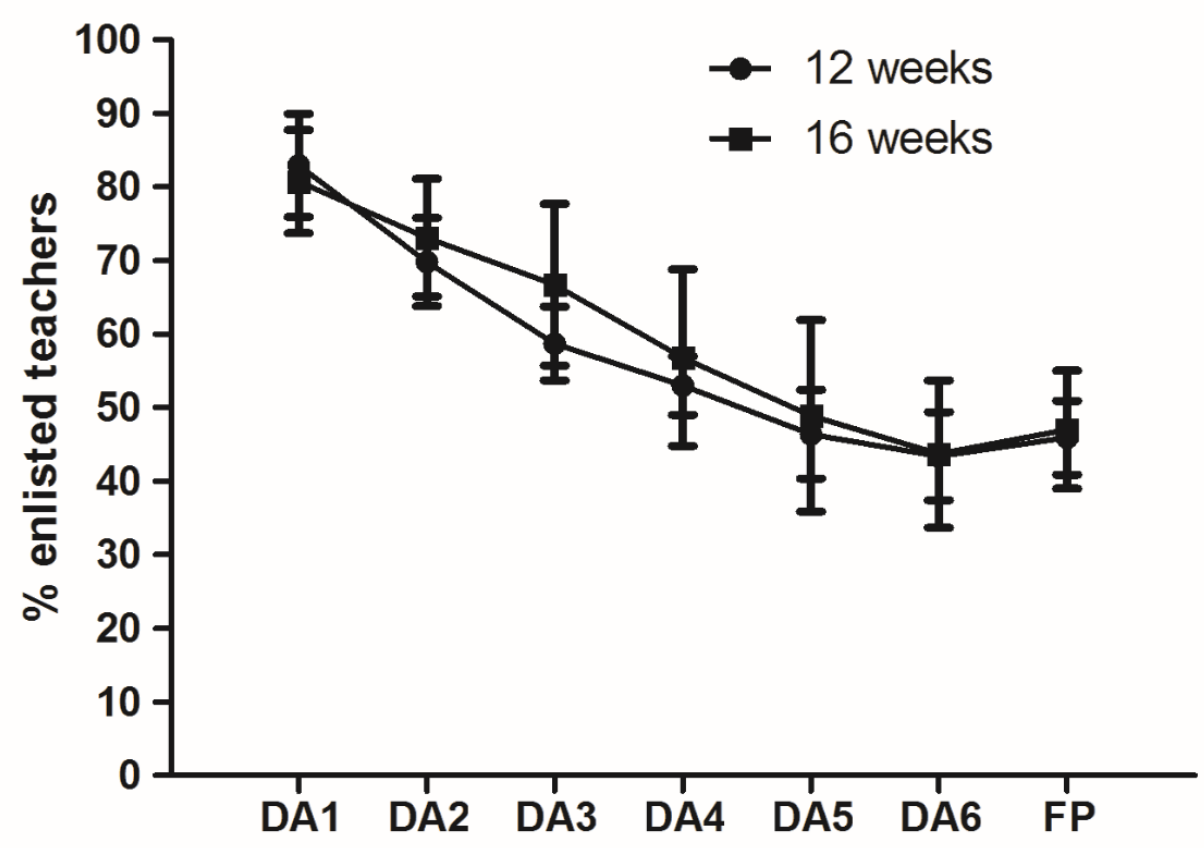

Figure 1. Persistence in online courses as indicated by the percentage of teachers that delivered each distance activity (DA) or the final paper (FP) on the corresponding deadlines.

\section{Profiles of Persistent Teachers}

We compared persistent teachers and dropouts concerning the sociodemographic data available (Table 3 ). No significant differences were found between them considering gender, age, frequency of internet use, and average number of internet tools used. Moreover, the percentages of teachers that used each of the internet tools surveyed were also indistinguishable (Figure 2).

Table 3

Participants'Self-Reported Demographic Data

\begin{tabular}{|c|c|c|c|c|}
\hline & & $\begin{array}{c}\text { Persistents } \\
(n=1569)\end{array}$ & $\begin{array}{l}\text { Dropouts } \\
(n=1386)\end{array}$ & $p$ value \\
\hline \multirow[b]{2}{*}{ Gender } & \multirow{2}{*}{$\begin{array}{l}\text { Male } \\
\text { Female }\end{array}$} & $24.8 \%$ & $24.4 \%$ & \\
\hline & & $75.2 \%$ & $75.6 \%$ & $p=0.08^{* * *}$ \\
\hline Age & & $36.45( \pm 9.12)$ & $35.75( \pm 8.29)$ & $p=0.2294^{* *}$ \\
\hline Frequency of Internet use ${ }^{*}$ & & $6.04( \pm 1.58)$ & $5.93( \pm 1.65)$ & $p=0.1513^{* *}$ \\
\hline $\begin{array}{l}\text { Average number of Internet } \\
\text { tools used }\end{array}$ & & $6.90( \pm 2.46)$ & $6.67( \pm 2.42)$ & $p=0.1513^{* *}$ \\
\hline
\end{tabular}




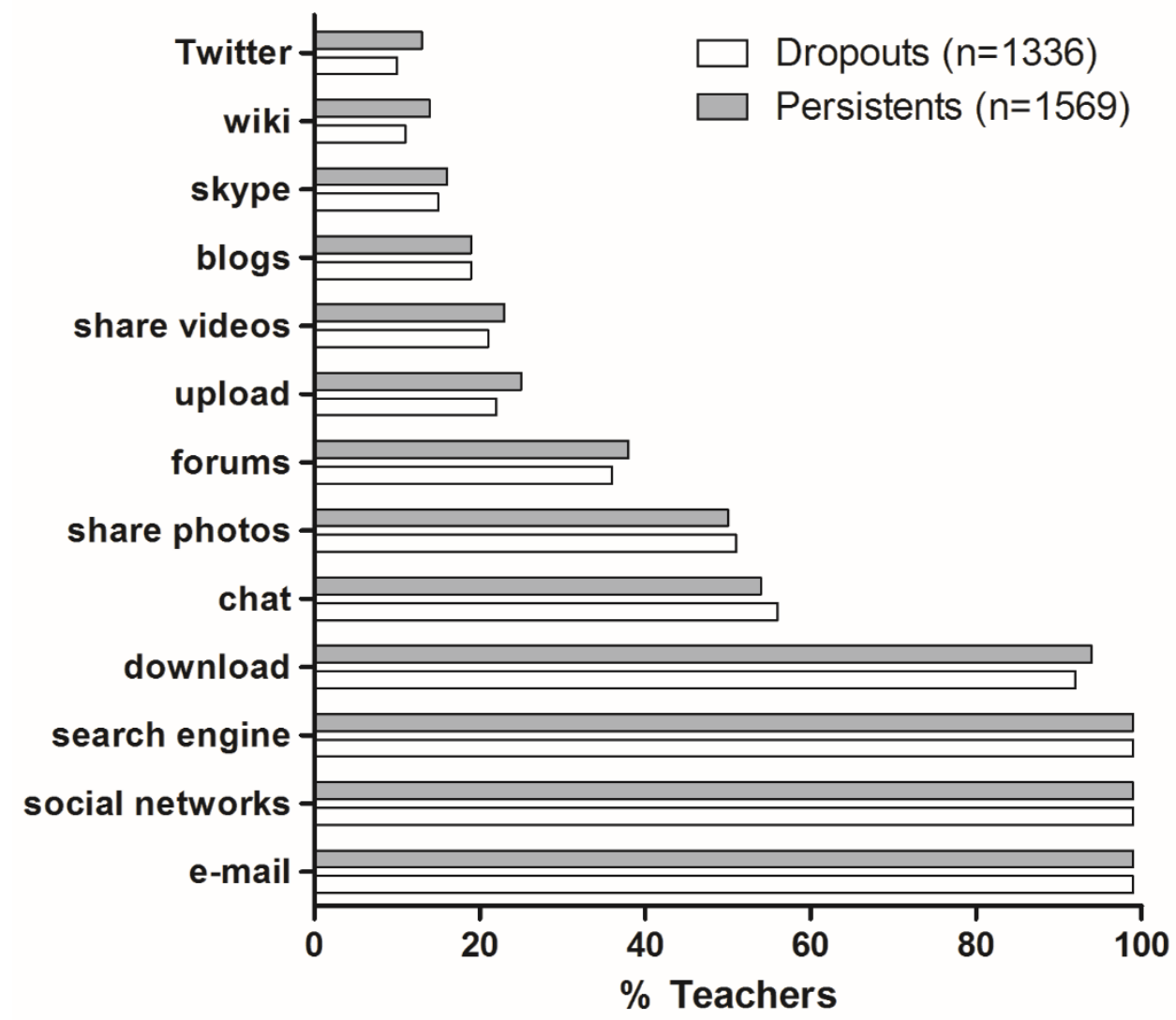

Figure 2. Use of 13 Internet tools by teachers.

\section{Understanding the Reasons for Dropping Out}

A follow-up procedure based on email messages and phone interviews was established to keep track of individual teachers during two courses. The procedure was aimed at trying to foster their participation and to identify possible reasons for dropping out of the courses. A total of 149 teachers out of the 188 that dropped out of those two courses were reached, either by e-mail $(n=45)$ or telephone $(n=104)$, resulting in a response rate of $79.3 \%$. The answers to email messages and to interviews fell into similar categories and were analyzed together. Pooled results are shown in Figure 3.

As shown in Figure 3, the most frequent category (40.3\%) that emerged from the answers comprised internal causes related to technological and technical issues (Park, 2007; Rovai, 2003). Technological problems were related mainly to difficulty in accessing the internet (16.9\%) or to not owning computers (8.7\%). Technical issues included difficulty in dealing with a courses' platform (12.1\%) or other software issues (2.6\%). 


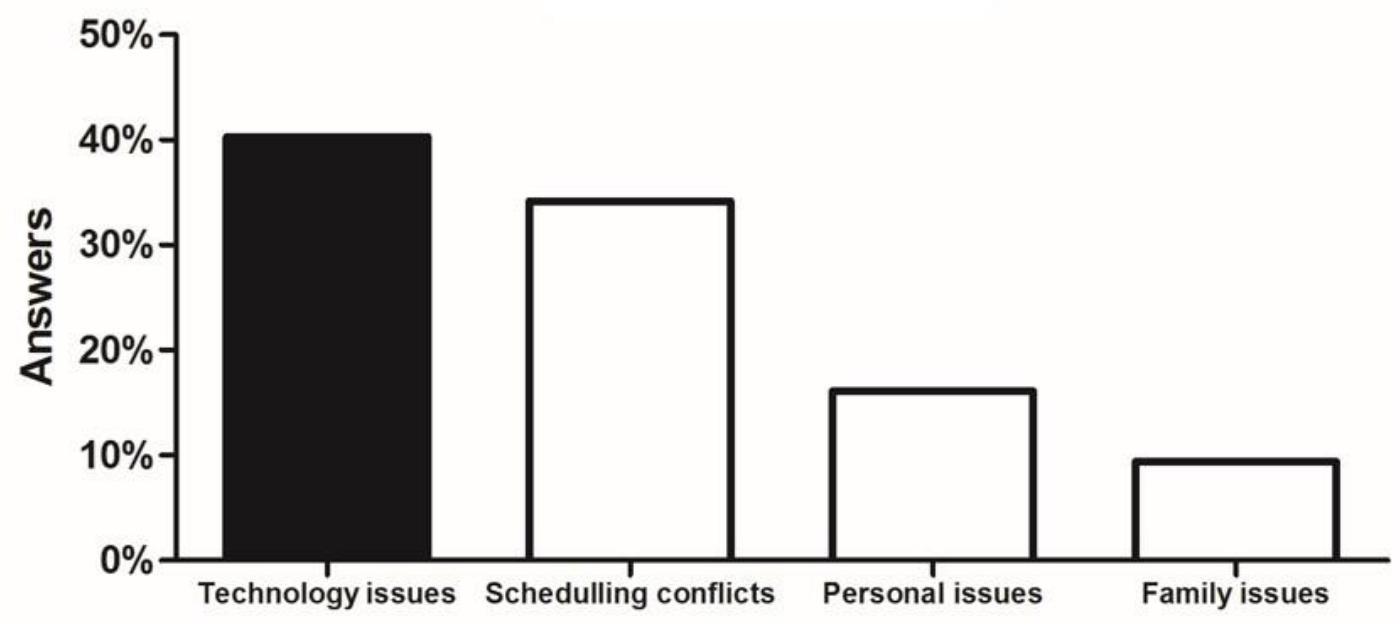

Figure 3. Teachers' (n=149) self-reported reasons for abandoning online courses. Internal (black bars) and external causes (white bars) are defined based on Park \& Choi (2009) theoretical framework. Adapted from "Factors influencing adult learners' decision to drop out or persist in online learning," by J. Park and H. Choi, 2009, Educational Technology \& Society, 12(4), 207-217. CC-BY-NC-NC 3.o.

However, the majority (59.7\%) of the reasons reported by teachers for dropping out were external in nature (Figure 3, white bars). The scheduling conflicts mentioned as reasons for dropping out of the courses by $34.2 \%$ of the teachers were a consequence of the excessive workload related to the required number of lessons to be taught weekly in several different workplaces. According to the teachers, that overload made it difficult for them to cope with the DAs and to keep track of the activities, thus leading them to drop out. Answers provided in the personal issues category (16.1\%) were mainly related to health problems (9.4\%) that rendered it impossible for the teachers to do the courses. Family issues were also frequently reported (9.4\%), which demanded substantial time from the teachers who needed to spend time with their children or caring for their relatives' health. The remaining teachers (6.7\%) used general expressions such as "family problems" or "family complications" as reasons for dropping out.

\section{Discussion}

Comparing dropout rates of different online courses is a rather complicated task. The dropout rates depend on the educational settings studied. Lower dropout rates are more common among undergraduate students and may be as low as $18 \%$ when students face financial penalties for dropping out (Levy, 2007). A slightly higher dropout rate (23.9\%) was reported for undergraduate students in regular online university courses not aimed at non-traditional learners (Nistor \& Neubauer, 2010). However, Levy's (2007) study was based on a definition of a dropout student that excluded learners that left the course at early stages when they faced no financial penalty for leaving. A dropout rate of $39.2 \%$ would have been achieved even without 
financial incentives if the teachers who never joined the courses were also excluded from our sample. The global dropout rate reported in the present work (53.1\%) results from the combination of two different processes: a sort of no-show phenomena, in which teachers never effectively joined the courses nor handed in any of the scheduled activities and a complementary and more substantial gradual process of dropping out during the courses. That pattern is not uncommon. Grau-Valldosera and Minguillón (2014) reported that about $20 \%$ to $30 \%$ of the students drop out of their courses in the first semester while the other dropout students gradually leave their courses later. Massive online open courses (MOOCs) are known to suffer with high levels of attrition and high dropout rates that may reach 90\%. Those high dropout rates are due to several, and sometimes controversial, causes. (Veletsianos \& Shepherdson, 2016). Although MOOCs are remarkably different from most other OPDP, a recent study analyzing MOOCs for non-traditional adult learners also described a combination of a no-show process (only $5 \%$ of the learners joined the courses) followed by a gradual dropout process (Eriksson, Adawi, \& Stohr, 2017).

A dropout rate of $53.1 \%$ is compatible with other reports for adult learners enrolled in online courses. Indeed, Park and Choi (2009) reported dropout rates ranging from $46 \%$ to $54.2 \%$ for non-traditional adult learners enrolled in job-related online courses. Similarly, Lykourentzou et al. (2009) reported a dropout rate (44\%) for adults with different educational backgrounds in introductory e-learning courses. As mentioned previously, reports on dropout rates in OPDP for teachers are rare. Russel et al. (2009) reported a dropout rate of $47 \%$ among math teachers enrolled in online courses. Although that dropout rate was lower than those reported here, the teachers who completed those courses in Russel et al.'s (2009) study, did receive financial incentives. A study of a one year long professional teacher development program reported a dropout rate of $40 \%$ for both online and face-to-face strategies, but again the teachers who completed the program received financial incentives and the drop-rate rate excluded the teachers who never effectively joined the project (Kubitskey et al., 2012). More recently, Stiller and Bachmaller (2017) reported a dropout rate of $34.1 \%$ among 574 trainee teachers registered in an online training course comprising eight modules of up to 90 minutes each (resulting in 18 hours of total workload). In that study, teachers were considered dropouts only if they failed to complete at least one module. That definition makes it difficult to compare their results with those obtained here. The courses analyzed herein had total workloads of 30 hours and were offered during shorter periods. If only the teachers who completed the eight modules in Stiller and Bachmaller (2017) study were considered as persistent it would result in a dropout rate of 66.3\%.

The dropout rates of online courses for teachers in developed or developing countries are likely to differ, as the educational conditions in the latter countries are also very distinctive. The strategies to reduce dropout rates that are effective in developed countries may prove unfruitful in other contexts. Although little is known about attrition in online professional development courses for teachers in developing countries, some inferences seem valid. Dropout rates are known to decrease as a consequence of financial penalties and certification (Levy, 2007; Rovai, 2003) However, the possibility of facing financial penalties when abandoning the courses would probably demotivate Brazilian teachers. Indeed, recent reports show that Brazilian teachers' wages are the second lowest among OECD countries, with little improvement in later stages of their career (OECD, 2014). It is thus unlikely that those teachers would risk facing such penalties.

The dropout rates reported here are unlikely to be related to course contents, as similar rates were reported for all courses analyzed. Grau-Valldosera and Minguillón (2014) also reported varying dropout rates 
(ranging from $37.3 \%$ up 65.6\%) in different programs offered by the Universitat Oberta de Catalunya. The dropout pattern is also unlikely to be related to course duration or intrinsic workload because both the total dropout rates and the pattern of dropping out that took place more gradually are quite similar in shorter (12-week) and longer (16-week) terms. That finding is somewhat contradictory with the high percentage of teachers (34.3\%) that reported scheduling conflicts as their main reasons for dropping out. It can still be argued that the 16-week courses were still too demanding for Brazilian teachers that are known to be subjected to an excessive workload (Lapo \& Bueno, 2003; Villani et al., 2009).

The persistent teachers were indistinguishable from those that left the courses regarding the available sociodemographic data (gender proportions and age). Similar results were obtained by Levy (2007). Hart's (2012) review also found that demographic factors were neither barriers nor facilitators to leaners' persistence in online courses. There were no differences between persistent teachers and dropouts regarding their technological skills. Rovai's (2003) framework included computer skills and the ability to deal with computer-based interactions among the skills relevant for persistency (Rovai, 2003). Park and Choi (2009), on the other hand, suggested that empirical evidence to support the impact of a learners' skills on the dropout rates in distance education was still unavailable. Although the data on teachers' technological skills analyzed in this study was far from exhaustive, we found no differences between persistent teachers and dropouts regarding several factors related to internet and computer use. Those findings may indicate that the teachers' internet-related skills did not play major roles in their decision to leave the courses. This conclusion is corroborated by a study that analyzed the influence of variables, such as teachers' computer attitudes and computer anxiety on dropout rates, and found no significant differences between persistent students and dropouts (Stiller \& Bachmaller, 2017).

In the present work, teachers' answers to telephone interviews and email messages were used to investigate self-reported reasons for leaving courses. The decision to contact teachers during the courses as soon as a potential dropout was identified is likely to have allowed the teachers to be contacted near the time when they decided to leave the courses. Teachers were also contacted without prior notice. We believe that this approach may have led to more reliable answers as it neither demanded teachers to recall reasons for their past decisions nor left time for them to elaborate on answers aimed at pleasing the interviewer.

Several studies have reported factors that lead learners to dropping out of online courses. The number of relevant factors reported varies significantly, ranging from 14 (Packham, Jones, Miller \& Thomas, 2004) to 69 (Lee \& Choi, 2011). In general, those factors are grouped in categories that are either related to learner, environmental, or course factors. Park and Choi (2009) emphasized the importance of organizational support and course relevance to life in the case of non-traditional learners, reinforcing Levy's (2007) idea that relevance and student satisfaction are key factors for persistence. In the present study, certification had no impact whatsoever on the teachers' career, but no teacher mentioned the lack of relevance as a factor that contributed to their decision to leave the courses. The teachers' replies to email messages and phone calls fit the categories of Park's (2007) framework. The majority of the answers (59.7\%) fell within categories grouped as external factors, mainly scheduling conflicts, personal, and family issues. The predominance of external factors among non-traditional adult learners is not uncommon. This finding agrees with the results of a recent study showing that physical constraint (a comprehensive external factor that comprises schedule conflicts, increased workload, child rearing, and personal disease) showed a strong 
negative correlation with persistence among students from undergraduate courses (Choi \& Park, 2018). The most commonly alleged external factor behind dropping out in the present study was related to scheduling conflicts (34.2\%). Such conflicts were connected to a learners' workload, a finding that is in agreement with several reports on the causes of high dropout rates in the context of online courses (Packham et al., 2004; Park, 2007; Park \& Choi, 2009; Rovai, 2003). Teachers' heavy workloads is a well-known phenomenon (Ballet \& Kelchtermans, 2009; Klassen \& Chiu, 2010) and has also been reported as a reason for dropping out in a study about online professional development programs (Kubitskey et al., 2012). Family issues, mostly the need to interrupt the courses to support sick family members, were also common as were issues related to the teachers' own health. Those findings are especially relevant in Brazil, where excessive work hours in multiple jobs can lead to burnout among teachers (Carlotto, 2011).

Internal factors accounted for a relevant proportion of the answers (40.3\%) and could be grouped within the technology issues category (Park, 2007; Park \& Choi, 2009). The teachers that enrolled in the courses analyzed in the present study are frequent internet users and use a broad variety of internet tools, a finding that is compatible with a previous study that characterized Brazilian teachers' use of internet tools (Rolando et al., 2013). Only $12.3 \%$ of the teachers mentioned the instructional design as a reason for abandoning the courses, suggesting that changes in the courses' general features would have little effect on the dropout rates. The low speed of their internet connections and the frequent connection failures accounted for a greater proportion of answers than issues related to the course platform. Although improvements on school-based internet access and computer availability have been documented in Brazil (Fidalgo-Neto et al., 2009) it is also unlikely that those improvements could have a relevant impact on dropout rates from the courses, because most teachers access the internet from their homes (CETIC, 2013) probably due to the constant commuting between their multiple jobs. On the other hand, it is reasonable to expect that improvements on the quality of internet connection that teachers have at home could substantially reduce dropout rates in online courses.

\section{Conclusion}

Public policies have recently been implemented in Brazil to promote teacher online development programs. We have shown that dropout rates in those courses are high and probably unrelated to the characteristics of the courses. The lack of time due to a heavy workload as well as technological issues associated with the quality of the internet connection that teachers have access to accounted for most of the reasons for dropping out. These results suggest that increasing the opportunities for teachers to enroll in online courses in Brazil will not suffice. Currently, professional development programs have little or no impact on the teachers' careers or wages in Brazil (Villani et al., 2009). Dropout rates in OPDP would likely fall if such programs had a positive impact on teachers' careers. It seems that the players involved in providing online courses for teachers (e.g., schools, universities, and government agencies) should develop partnerships to offer at least temporary financial incentives and reduced workload to reduce attrition and make it feasible for Brazilian teachers to complete courses. Further large-scale studies are needed to determine whether or not the reasons that lead Brazilian teachers to drop out of the courses studied here reflect a general pattern. 
It is also necessary to investigate whether those findings apply to similar contexts in other developing countries. 


\section{References}

Allen, I. E., \& Seaman, J. (2016). Online report card: Tracking online education in the United States. Babson Survey Research Group and Quahog Research Group, Needham, MA. Retrieved from http://onlinelearningsurvey.com/reports/onlinereportcard.pdf

Ballet, K., \& Kelchtermans, G. (2009). Struggling with workload: Primary teachers' experience of intensification. Teaching and Teacher Education, 25(8), 1150-1157. http://doi.org/10.1016/j.tate.2009.02.012

Bean, J., \& Metzner, B. (1985). A conceptual model of nontraditional undergraduate student attrition. Review of Educational Research, 55(4), 485-650. https://doi.org/10.3102/00346543055004485

Bersin, J. (2005). The four stages of e-learning: A maturity model for online corporate training. Oakland, CA: Bersin \& Associates.

Borman, G. D., \& Dowling, N. M. (2008). Teacher attrition and retention: A meta-analytic and narrative review of the research. Review of Educational Research, 78(3), 367-409.

http://doi.org/10.3102/0034654308321455

Ministério da Educação. (2010). Resumo Técnico: censo da educação superior de 2009 [Brief technical report: high education census 2009] Brasília, DF. Instituto Nacional de Estudos e Pesquisas Educacionais Anísio Teixeira (INEP/MEC). Retrieved from http://download.inep.gov.br/download/superior/censo/2009/resumo tecnico 2009.pdf

Carlotto, M. (2011). The Burnout syndrome in teachers: prevalence and associated factors. Psicologia: Teoria E Pesquisa, 27(4), 403-410. Retrieved from http://www.scielo.br/pdf/ptp/v27n4/o3.pdf

Cetic - Centro Regional de Estudos para o Desenvolvimento da Sociedade da Informação [Local center for the studies on the developmentof the information Society]. (2013). Pesquisa sobre o uso das TIC nas escolas brasileiras: TIC Educação 2012. São Paulo [Survey on the use of internet in Brazilian schools: Communication and information Technologies 2012]. Comitê Gestor da Internet no Brasil. Retrieved from http://cetic.br/media/analises/apresentacao-tic-educacao-2012.pdf

Choi, H. J., \& Park, J. H. (2018). Testing a path-analytic model of adult dropout in online degree programs. Computers and Education, 116, 130-138. http://doi.org/10.1016/j.compedu.2017.09.005

Conferência Nacional de Educação. (2010). Construindo o sistema nacional articulado de educação: o plano nacional de educação, diretrizes e estratégias: Documento final (Building the National Integrated Educational System: the National Educational Plan, guidelines and strategies: Final document). Brasília, DF: MEC. Retrieved from http://Conae.mec.gov.br/images/stories/pdf/pdf/doc base documento final.pdf 
Eriksson, T., Adawi, T., \& Stöhr, C. (2017). "Time is the bottleneck": A qualitative study exploring why learners drop out of MOOCs. Journal of Computing in Higher Education, 29(1), 133-146. http://doi.org/10.1007/s12528-016-9127-8

Favero, R., \& Franco, S. (2006). A study on the persistence and the evasion in distance education. RENOTE - Revista Novas Tecnologias Na Educação, 4(2), 1-10. Retrieved from https://seer.ufrgs.br/renote/article/view/14295/8212

Fidalgo-Neto, A., Tornaghi, A. J. C., Meirelles, R. M. S., Berçot, F. F., Xavier, L. L., Castro, M. F., \& Alves, L. A. (2009). The use of computers in Brazilian primary and secondary schools. Computers \& Education, 53(3), 677-685. http://doi.org/10.1016/j.compedu.2009.04.005

Fishman, B., Konstantopoulos, S., Kubitskey, B. W., Vath, R., Park, G., Johnson, H., \& Edelson, D. C. (2013). Comparing the Impact of online and face-to-face professional development in the context of curriculum implementation. Journal of Teacher Education, 64(5), 426-438.

http://doi:10.1177/0022487113494413

Fraenkel, J. R., \& Wallen, N. (2003). How to design and evaluate research in education. New York, NY: McGraw-Hill.

Frydenberg, J. (2007). Persistence in university continuing education online classes. International Review of Research in Open and Distance Learning, 8(3), 01-15. http://doi.org/10.19173/irrodl.v8i3.375

Grau-Valldosera, J., \& Minguillón, J. (2014). Rethinking dropout in online higher education: The case of the universitat oberta de catalunya. International Review of Research in Open and Distance Learning, 15(1), 290-308. http://dx.doi.org/10.19173/irrodl.v15i1.1628

Hart, C. (2012). Factors associated with student persistence in an online program of study: A review of the literature. Journal of Interactive Online Learning, 11(1), 19-42. Retrieved from http://www.ncolr.org/issues/jiol/v11/n1/factors-associated-with-student-persistence-in-an-onlineprogram-of-study-a-review-of-the-literature

Ingersoll, R. \& Perda, D. (2009). The mathematics and science teacher shortage: Fact and myth. CPRE Research Reports. Retrieved from http://repository.upenn.edu/cpre researchreports/51

Karsenti, T., \& Collin, S. (2013). Why are new teachers leaving the profession? Results of a Canada-wide survey. Education, 3(3), 141-149. http://doi.org/10.5923/j.edu.20130303.01

Kember, D. (1989). A longitudinal-process model of drop-out from distance education. The Journal of Higher Education, 6o(3), 278-301. Retrieved from http://www.jstor.org/stable/1982251

Kennedy, D., \& Powell, R. (1976). Student progress and withdrawal in the Open University. Teaching at a Distance, 7, 61-75. 
Kenski, V. (2009). Educação e tecnologias: o novo ritmo da informação (5th ed.). Campinas, SP: Ed. Papirus.

Klassen, R. M., \& Chiu, M. M. (2010). Effects on teachers' self-efficacy and job satisfaction: Teacher gender, years of experience, and job stress. Journal of Educational Psychology, 102(3), 741-756. http://doi.org/10.1037/a0019237

Kubitskey, B. W., Vath, R. J., Johnson, H. J., Fishman, B. J., Konstantopoulos, S., \& Park, G. J. (2012). Examining study attrition: Implications for experimental research on professional development. Teaching and Teacher Education, 28(3), 418-427. http://doi.org/10.1016/j.tate.2011.11.008

Lapo, F. R., \& Bueno, B. O. (2003). Teachers, disenchantment in the profession and quitting the public schools. Cadernos de Pesquisa, (118), 65-88. http://doi.org/10.159o/So100-15742003000100004

Lee, Y., \& Choi, J. (2011). A review of online course dropout research: implications for practice and future research. Educational Technology Research and Development, 59(5), 593-618. http://doi.org/10.1007/s11423-010-9177-y

Levy, Y. (2007). Comparing dropouts and persistence in e-learning courses. Computers \& Education, 48(2), 185-204. http://doi.org/10.1016/j.compedu.2004.12.004

Lykourentzou, I., Giannoukos, I., Nikolopoulos, V., Mpardis, G., \& Loumos, V. (2009). Dropout prediction in e-learning courses through the combination of machine learning techniques. Computers \& Education, 53(3), 950-965. http://doi.org/10.1016/j.compedu.2009.05.010

Macdonald, D. (1999). Teacher attrition: A review of literature. Teaching and Teacher Education, 15(8), 835-848. http://doi.org/10.1016/So742-051X(99)ooo31-1

Meister, J. (2002). Pillars of e-learning success. New York: Corporate University Exchange.

National Research Council. (2007). Enhancing professional development for teachers: Potential uses of information technology. Washington, D.C: The National Academic Press.

Nistor, N., \& Neubauer, K. (2010). From participation to dropout: Quantitative participation patterns in online university courses. Computers \& Education, 55(2), 663-672.

http://doi.org/10.1016/j.compedu.2010.02.026

OECD. (2014). Education at a glance 2014: OECD indicators. "Indicator D3: How much are teachers paid?”. In Education at a Glance 2014: OECD Indicators, Paris: OECD Publishing. https://doi.org/10.1787/eag-2014-31-en

Packham, G., Jones, G., Miller, C., \& Thomas, B. (2004). E-learning and retention: Key factors influencing student withdrawal. Education \& Training, 46(6), 335-342. https://doi.org/10.1108/00400910410555240 
Park, J. (2007). Factors related to learner dropout in online learning. In F. M. Nafukho, T. H. Chermack, \& C. M. Graham (Eds.), Proceedings of the 2007 academy of human resource development annual conference (pp. 1-8). Indianapolis: AHRD. Retrieved from http://www.eric.ed.gov/ERICWebPortal/recordDetail?accno=ED504556

Park, J., \& Choi, H. (2009). Factors influencing adult learners' decision to drop out or persist in online learning. Educational Technology \& Society, 12(4), 207-217.

Rolando, L. G. R., Salvador, D. F., \& Luz, M. R. M. P. (2013). The use of internet tools for teaching and learning by in-service biology teachers: A survey in Brazil. Teaching and Teacher Education, 34, 46e55. http://dx.doi.org/10.1016/j.tate.2013.03.007.

Rovai, A. P. (2003). In search of higher persistence rates in distance education online programs. The Internet and Higher Education, 6(1), 1-16. http://doi.org/10.1016/S1096-7516(02)00158-6

Russell, M., Carey, R., Kleiman, G. \& Venable, J. D. (2009). Face-to-face and online professional development for mathematics teachers: a comparative study. Journal of Asynchronous Learning Networks, 13(2), 71-87. Retrieved from http://files.eric.ed.gov/fulltext/EJ862349.pdf

Salvador, D.F., Crapez, M.A.C., Rolando, R.F.R., Rolando, L.G.R., \& Magarão, J.F.L. (2010). An overview of the continuing training of biology and science teachers through distance education in Rio de Janeiro state. EAD em Foco, 1, p. 59-58. http://dx.doi.org/10.18264/eadf.v1i1.19

Stiller, K. D., \& Bachmaier, R. (2017). Dropout in an online training for trainee teachers. European Journal of Open, Distance and e-Learning, 2O(1), 80-94. https://doi.org/10.1515/eurodl-20170005

Tinto, V. (1993). Leaving college: Rethinking the causes and cures of student attrition (2nd Ed.). Chicago: University of Chicago Press.

UNESCO. (2008). ICT competency standards for teachers. Paris, France.

Veletsianos, G., \& Sheperdson, P. A. (2016). Systematic analysis and synthesis of the empirical MOOC literature published in 2013-2015. The International Review of Research in Open and Distributed Learning, 17(2), 198-221. http://dx.doi.org/10.19173/irrodl.v17i2.2448

Villani, A., Almeida-Pacca, J. L., \& Freitas, D. (2009). Science teacher education in Brazil: 1950-2000. Science and Education, 18(1), 125-148. http://doi.org/10.1007/s11191-007-9116-4

Yukselturk, E. (2010). An investigation of factors affecting student participation level in an online discussion forum. The Turkish Online Journal of Educational Technology, 9(2), 24-32. Retrieved from https://www.learntechlib.org/p/55661/ 


\section{Appendix A}

\section{Text of the Email Message Sent to the Teachers}

Dear teacher,

You have not accessed the virtual classroom of the course (name of the course) during the last weeks. Please, feel free to contact us in case you are experiencing difficulties in accessing the classroom or facing other issues that are preventing you from doing the course. We will be glad to assist you in any way so that you can continue attending the course.

Best regards,

Fundação Cecierj - Outreach Team 


\section{Appendix B}

\section{General Structure of the Phone Call Made to Teachers}

Tutor: Greetings. I am (caller's fictional name) a tutor with the CECIERJ foundation. We are calling you to talk about the course (cites name of the course) you are enrolled in. We have noticed that you have not accessed the virtual classroom for quite a long time. Is there anything that I can do to help you? May I assist you with anything that might help you rejoin the course? (in case of a negative answer) Would you like to share the reasons that lead you leave the course?

Thank you, Fundação Cecierj - Outreach Team

\section{Athabasca}

University

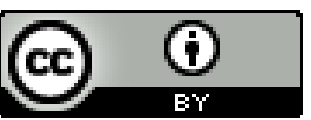

